\title{
The Relationship Between Staff Development, Organizational Policy, Staff Welfare to Personnel Performance
}

\author{
Naziru Mohammed Musalli* \\ Azhar Harun \\ Ruslam Zainnudin \\ School of Government, College of Law Government and International Studies, Universiti Utara Malaysia \\ Email: muserlly@gmail.com
}

\section{Doi:10.5901/mjss.2015.v6n4p288}

\begin{abstract}
Nigeria Immigration Service (NIS) is one of the most important agency tight with the responsibility of Border management, Although the agency perform many functions other than patrolling borders ranging from issuance of e- passport and visa as well as checking travellers document. The organization played a significance role in controlling movement of illegal immigrants and other organised criminal activities in border zones. As border management become a central issue of concern in the contemporary global arena. In spite of the existence of many agencies of border management, still it is confronted with a lot of challenges as a result of increasing flows of people, goods and services across regional borders. The porosity of Nigerian borders coupled with manpower challenges that can properly mount the border affect the economic growth in the country. Massive influx of illegal immigrants with proliferation light arms and many form of contraband goods organized criminal activities, affect national security and economic development in Nigeria especially in the north/eastern part of the country as focal area of this study considerable number of questionnaires was distributed in the field and the data was analysed quantitatively using PLS Statistical package. In the conclusion this study suggestions would be given more concern of investigating a proper way to improve the performance of personnel in Nigeria Immigration Service (NIS) in order to achieve the purpose of this study.
\end{abstract}

Keywords: Border Management, Insecurity, Porosity of Border, Border Personnel, Nigeria Immigration Service.

\section{Introduction}

Nigeria Immigration Service (NIS) is one of the most important agency tight with the responsibility of Border management, Although the agency perform many functions other than patrolling borders ranging from issuance of e- passport and visa as well as checking travellers document. The organization played a significance role in controlling movement of illegal immigrants and other organised criminal activities in border zones. As border management become a central issue of concern in the contemporary global arena. In spite of the existence of many agencies of border management, still it is confronted with a lot of challenges as a result of increasing flows of people, goods and services across regional borders. The porosity of Nigerian borders coupled with manpower challenges that can properly mount the border affect the economic growth in the country. Massive influx of illegal immigrants with proliferation light arms and many form of contraband goods organized criminal activities, affect national security and economic development in Nigeria especially in the north/eastern part of the country as focal area of this study. In the conclusion this study suggestions would be given more concern of investigating a proper way to improve the performance of personnel in Nigeria Immigration Service (NIS) in order to achieve the purpose of this study.

Management of border is becoming a sensitive area of concern especially in current trend of contemporary globalize world. Globalization has led to increasing flows of people, goods and services across regional borders Border in the technical sense refers to an area or region nearer to a boundary, in most of the Anglo American literatures it usually describe as boundaries or a divided line between politically sovereign territorial entities (Magaret 2011). While In this article perspective, it is viewed in terms of invisible margins and legitimate jurisdiction of political units such as sovereign states, federal state, it also seen as the main line which demarcates a country to another. Therefore border simply define geographical governments and sub national entities. Moreover, they are equally regarded as a solid picture of people's cultural value systems and their identification as statehood. While in the continent of Africa, several opinions were 
advanced with regard to the arbitrary nature of the boundary demarcation as result of colonial exploitation which was rather truncated and distorted the cultural systems of the Africans. Border management means the administration of borders, which concerns with rules, procedures, processes, and techniques regulating the activities and traffic across defined border zones. The administration that gives an appropriate balance between preventing illegal immigrant entry and remained open to legal trade for the benefit of the countries (Mackay, 2008).

Nigeria has reasonable number of institutions and agencies charged with responsibility of managing borders, example Custom Service, National Drugs Law Enforcement Agency (NDLEA), Nigeria Immigration Service (NIS) among others. For the purpose of this study Nigerian Immigration Service (NIS) as an institution is selected as the focal area of study, where the main functions of the agency is to secure the in and out flow of people entry, issuance of passport, visa (entrance) permit, as well as controlling illegal immigrant and proliferation of light arms in the country. Despite all this, the country keep experiencing growing number of deadly insurgencies that have a devastating effect on its economic development and security challenges. Thus, these research works intends to examine the performance of personnel in Nigeria Immigration Service in countering the aforementioned problems.

The objective of this study is identifying the relationship between staff development, organization policy and funding of staff welfare that influence the quality of staff performance of border management personnel in Nigeria Immigration Service (NIS).

\section{Literature Review}

The importance role played by Nigeria Immigration Service in border management on enhancing the socio-economic and political development of West African regions, Nigeria in particular cannot be over emphasised. Apart from the responsibilities of the agency in promoting political stability based on securing the borders of the country, the regulation enhances the economic activities integration in terms of free movement of people, goods and services within the regions (Addo, 2006).The roles of Nigeria Immigration Service personnel in managing border of controlling illegal activities which has devastating effect to the national security and economic development of the country at large. Even though the agencies responsible for border control have been making concerted efforts to curtail illegal activities such as smuggling, human and drugs trafficking, proliferation of small arms and light weapons as a result of existing porous borders in the region but they still confronted with many challenges (Prosper, 2006).

\subsection{Staff Performance}

Staff performance is associated with the quality of output in relation to the timely, effective and efficient effort put in of a given task set on mutual agreement between employee and employer in running the organization (Mathis \& Jackson 2009). Staff performance is the successful completion of tasks by selected individuals as set and measured by overseer or organization to pre- defined acceptable standard with effective and efficient utilization of available resources within a changing environment.

Organizational support is refers to employee's perception of the concern shows for their well-being in the organization. Organization support should be tilted toward boosting employees moral through involvement and commitment which eventually impact positively to job performance of organization. Wayne et al., (1997) figured out a positive relationship in using human resource management practices that is development al in nature and organizational support help in quality of service and productivity. Moreover, the high level of perceived organizational support result to a mandatory sense and obligation of staff fought to be committed to the organization. Even further fell mandatory in putting their best effort in favour of organizational job performance. Eisenberger et al., (1990) in his work shown that perceived organizational support is positively related to conscientiousness, commitment and innovation in carrying out the responsibilities of job performance in organization. The concept is being valued and cared by the organization in which exchange in recognising and rewarding desired personnel performance in praise, salary and promotion increases is require commensurate to their commitment of job performance.

\subsection{Staff Development}

According Raja, Furqan \& Muhammed (2011) asserted that the important of human resource were highlighted that is considered as the backbone of every organization. Most of the organizations intend to invest huge amount of capitals in human resource department because it is the major area that will ultimately improves the performance of organization toward achieving goals and objectives. The improvement of performance increases effectiveness and efficiency in 
organization and assist the organization for the achievement of it goals in the long run. Certain factors were identified which help in improving work of staff are flexible schedules and training among others. Staff development has been described as the process of developing personnel that can assist the organizations to ensure its members possess the skills and knowledge they require as the basic requirement needed in performing jobs effectively. It is apparently clear that most of the organization and agencies do not seriously invested in on-going quality staff development and training (Angela, Joyce \& Marcia, 2003).

Armstrong (2000) ascertain the important of training design is very helpful to organizational objectives and the organization to excel, there is need to figure out employees interest according to their needs. Seems training design play an important roles in organizational performance, therefore unorganised training design lead to organizational waste of both resources and time. Modern organizations nowadays mostly engage in their employees with on the job training based on realisation of certain advantages related to this form of training i.e on the job training is cost effective and time savings. It is also recommended the system because it gives the staff opportunity to learn practical aspects in the organization. An organization to be able to compete with current global challenges it is necessary to embark on training and development programme. Although the effect of training is directly related to staffs because of the skills and knowledge acquired by employees, but eventually the benefit will trickle down to the organizations (Raja, Faurqan \& Muhammaed, 2011). In the final analysis this research intends to brings out several factors for the organizations, in considering the important of training and development, also an effort to give insight for organization in understanding the necessary of training employees with regards to the achievement of organizational goals and objectives.

Michael (2006) describes human resource management as strategic and intelligible method of management in an organization. It is a place where the most valuable human resources individuals who collectively cooperate together and contribute to the achievement of organizational objectives. The main purpose of human resource department is assuring the organization attainment of maximum level of productivity to the achievement of success using organizational manpower. Basically human resource management mostly concern with the achievement of the stated organizational goals and objectives.

Training is the most effective strategy of developing organizational staff that can boost the moral and improve the quality of the existing personnel adequate skills and knowledge that can encourage them toward achieving organizational objectives (Roberson, 1997). Training and development support organizational members to have an adequate skills and knowledge in performing their jobs effectively.

\subsection{Policy of the Organization}

Morris \& Snell (2010). Posit that the policy perception and of Strategy of human resource management serve as determining key factor to the success of organization. Policies and practices can be seen as reciprocal in reinforcement that creates a strong impact on organizational goals attainment. However, human resource management policies are guided by the logical sense and skills that mostly developed in accordance with the requirements of business processes of the organizational activities (Serpell \& Ferrada, 2007). Thus, the policy strategy provides an apparatus to capture and communicate the important criteria that focus toward achieving organizational objectives. Therefore in the context of policies development to organization $s$ that allow human resource management to have an insight with regard to the policies initiation aims to identify to what extent they are applicable to the organizations that produce significance result in the long run. Modern trend of human resource management must also not be relegated to a traditional supportive role anymore, but instead must institute the necessary competency in reaching the organizational and individual objectives, since human resource are valuable aspect that constitute a source of competitive advantage in attainment of organizational goals. Uysal (2012) indeed found strong, positive and significant relationships among the main human resource management policies cited in the literature, such as staffing, training, performance evaluation and compensation in the organizational performance. These results are important in understanding the inter-relationships between human resource management practices in order to enhance the effective management of human resource systems on employee-based organizational performance. In this context, organizations have turned to the perspective of creating competitive advantage solely to improve the quality of service and productivity. Consequently, most of the organizational policy and theory come together, for the purpose producing comprehensive positive effects for human resource management in putting organizational goals as primary function as stake ( Demo et., al 2012).

According to Patric. (2013) in his study on common assessment framework indicated certain number of criteria's of improving organizational performance. Emphasise were given to the role leadership played as one of the most important factor by formulating sound policies, adaptation and implementation which would ensure the organization is taken the right direction. Making decision with clear mission, vision and focus toward achieving the core values of the organization. 
The mission of why the organization exists, while the vision implies the organizational ambition and the values is what steers out behaviour. Leaders are also expected to develop, implement and monitor policy of the organizations management system, through the application of appropriate structure of clear tasks at every level of staff in the organization which serve as medium of improving staff performance.

Strategy and planning is also principles posit in which the organization requires to develop a strategic objectives based on public policies guide lines. It is understood that most of the organizations open up to any kind innovation or decision taken from the top management that they fell will enable them to attain organizational objectives in the long run. (Staes, 2012). In the same vein, planning is an approach which involves settings of the objectives and identification of process with the aims of achieving the organizational goals. The study also emphasise the important role of human resource management that will enable personnel to contribute effectively toward accomplishment of organizational objectives. Human resource management is expected to develop and implement policy regarding to recruitment, promotion, remuneration, rewards much more importantly staff welfare, to improve the personnel performance in the organization. Another important aspect asserted in terms of Information knowledge in respect to information and communication technology as well as other technological policies should have a systematic way to get into the organization, as this will serve as panacea in improving the quality of personnel in performing organizational tasks. In view of the above, the relevance infrastructure needs to be managing effectively, so as to support the staff to have good working condition to discharge their duties effectively (Patric S. 2013).

\subsection{Staff Welfare in Organization}

Singh (2009) asserted that the quality of work life normally depends on the degree of staff welfare that employer provide to satisfy employees need. .In an effort to give a clear explanation of the concept of staff welfare the following items has been considered which their presence determine the level of commitment of organization on staff welfare. It is apparently clear that the existence of staff welfare helps and encourages personnel to improve their working environment which in the long run resulted to high quality performance in the organizational productivity. Provision of appropriate training, free medical treatment, sport facilities, social club, canteens, supervising staff and works, operating sick club and savings well fare schemes, providing advices on personal issues as well as arrangement of legal aids, staff pension funds and leave grants, giving loans especially on hardship situations, providing assistance to a transferred staff and above all giving assistance in all area of ramification that would make employees feel comfortable in organization (Coventry \& Barker 1988). Another factor that led to staff apathy and hinders the efficiency of personnel end result performance is delay of paying workers' salaries. It is obvious for all staff to have a specific monitory expenditure and failure to receive salary on promptly discourages their performance which affects the organisation in the long run (Okereke \& Daniel, 2010). While in the contrary up front salary encourages employees' physical, mental, moral and emotional well-being, it increases motivation and satisfaction and finally yield to positive result in the organizational maximum productivity.

It is also important to consider the issue regarding the provision of adequate training for staff development, better organizational policies and provision of funding to cater for both the organization and staff well fare would serve as panacea to performance of Nigeria Immigration personnel's. According to Seniora and Cedric, (2010) Border management partakes double task, to control and monitor in order to identify and screen undesirable persons, goods that could be a potential threat to the security that promote trade stability between neighboring countries. Performing these tasks requires series level of competencies for officials working at the borders zones and their motivational aspect should also be considered as well. This procedure encourage state apparatus in putting their best to fulfill a wide range of tasks from internal and external security as well as revenue collection responsibilities to enhance the country economic development.

The objective of this study is identifying the validity and the reliability of measurement instruments staff development, organization policy and funding of staff welfare that influence the quality performance of border management personnel in Nigeria Immigration Service (NIS).

\section{Methodology}

Methodology employed in conducting this study is quantitative in nature where by number of questionnaires was distributed in the study area in order to have respondents opinion performance personnel, as the procedure of data collection. 


\subsection{Sample}

The present study is carried out in selected zones in Nigeria Immigration Service (NIS). Zone C is the study unit of analysis in north/eastern part of the country and Zone A is in the south/western part of the country. The study comprises 71 respondents which among them 52 were male staff in the organization while the 19 among the respondents are female respectively.

\subsection{Instruments}

Data of the present study was collected using one instrument that contains 2 sections. Section A the constructs of both independent variables and dependent variable staff development, policy of organization, staff well fare fund, and staff performance as dependent variable. Section B is on demographic profile of the respondents. The instrument contains 43 items. Specifically staff development has 6 items, while policy contains 6 items respectively and staff welfare with only 5 items, lastly staff performance as dependent variable with 10 items and section B demographic profile of the respondents with 6 items. The respondents were asking to respond on the questionnaire to indicate the extent to which they agreed or disagreed with the statement based on 5 likert scale. The 1-5 likert scales in the questionnaire represent strongly disagree, disagree, neutral, agree and strongly agree respectively.

On the course of this paper only the independent variables of (staff development, policy, and staff welfare) as well as dependent variable of (staff performance) were used which measured the direct relationship between them, and reliability and validity of Cronbach's Alpha indicated that is highly reliable and suitable enough to conduct the main study.

\subsection{Data Analysis}

This study used SPSS (Statistical Packages of Social Science) version 18 to analyse the data collected in the field. The missing values were filled accordingly and out lair were screen out with aims of analysing validity and reliability for Cronbach's alpha and Pearson's coefficient correlation.

\section{Findings and Discussion}

The findings of this study indicated the validity and reliability of instruments employed in conducting the research are sufficient. Based on the data analyses collected from the field as well as the objectives of the study.

\subsection{Reliability Analysis}

Reliability is refers to as the strength and trustworthiness of the items used. It is one of the indicators of quality of measurement employ on the study. (Sekaran, 2003). Crobach's Alpha coefficient is used in this research to find out the internal reliability of scaled items by the investigation of the average inter-item correlation. Cronbach's Alpha coefficients above 0.60 are said to be sufficient enough for item reliability (Nunnally 1994). While In the present study Cronbach's Alpha was the method used to assess reliability of border management personnel.

The perception of respondents on staff development the scale consisted of 6 items and its Cronbach's alpha value is .826 (see Table 1), and it is considered to be suitable and reliability (Nunnally 1994). Concerning policy of organization the construct has 6 items. The Cronbach's Alpha value based on standardized items is .716 which is considered good enough based on Nunnally (1994) recommendation. (See Table 1).

In respect to the perception on Staff Welfare construct has only 5 numbers of items and the Cronbach's Alpha value based on standardized items shows the significance of .768 levels which is enough to justified acceptable level of validity and reliability as suggested by Nunnally (1994). See Table 1 for more clarification. In the same vein, the perception on Staff Performance construct has the number of 10 items. The reliability statistics reveals the Cronbach's Alpha value of .896 which is considered an acceptable value for testing reliability of instruments. See Table 1.

\section{Conclusion}

In conclusion, the instruments validation and reliability statistics provided suggested that all items are satisfactorily Cronbach's Alpha value for reliability standard. Therefore, the reliability factors of all items assessed of the research were adequately enough and suitably reliable and valid. Lastly the items were considered sufficiently enough in providing 
information on the border management personnel in Nigeria Immigration Service (NIS). The findings also shown relationship between policies of organization instruments justified there is strong relationship between those factors. This finding concerning instruments for measuring staff well fare on performance of border personnel in Nigeria provides suggested information on how to achieve the objective of border management. The findings will be useful in contribution to the body of knowledge that will be useful border control. The study will be important to policy makers in designing relevant policies concerning border management in Nigeria.

\section{References}

Adomi, E. E., (2007). A better response rate for questionnaires: Attitudes of Librarians in Nigeria University Libraries.

Addo, P. (2006). Cross Border Criminal activities in West Africa: Options for effective responses.

Aguinis, H. \& Kraiger, K. (2009). Benefits of training and development for individuals.

Alden, E. (2012). Immigration and Border Control

Ahmed, L.E. and $2^{\star}$ Chilaka, F.C. (2013). The political economy of criminality along Nigeria-Benin republic borders and worsening insecurity in Nigeria Journal of Social Sciences and Public Policy, Volume 5, Number 2, 2013.

Vines, A. (2005). Combating light weapons proliferation in West Africa. International Affairs, 81(2), 341-360..

Berry T. (2010). The changing border: developments and risks in border control management of western countries development in developing countries: lessons from Korea and Japans

Bello, H.M. (2003). The Role of information and communication technology in the fight against poverty: The Nigerian experience. Paper presented at the Symposium on ICT and the society of information, 9th-11 December, 2002, Algiers.

Bogdan, R., and Taylor, S.J. (1984). Introduction to qualitative research methods: The search for meaning. New York: John Wiley and Sons.

Briggs, B.R. (2007). Problems of recruitment in civil service: Case of the Nigerian civil service. African Journal of Business Management, 1(16), 142-153.

Creswel, J. (2007). Qualitative, quantitative, and mixed methods approaches. Second edition.

Cronbach, L.J. (1982). Designing evaluations of educational and social programs. San Francisco: Jossey-Bass.

David N. (2006). The lines that continue to separate us: borders in our borderless world.

Dennis, B., and Engbersen, G. (2007).The fight against illegal migration: identification policies and immigrant's counter strategies. American behavioural scientist, V. 50.

David V. Aguilar \& Micheal, J. Fisher (2010). 2012-2016 border patrol strategic plan.

Doyle, T. (2010). Collaborative border management World Customs Journal

Federal Republic of Nigeria (2008). Guidelines for appointments, promotion and discipline Issued by the federal civil service commission (FCSC) Abuja Nigeria

Hale, G. (2009) In search of effective border management a changing world: Canadian foreigh policy priorities no. 3 Canadian international du canada

Hadal, C. C (2010). Border Security: The role of the U.S border personnel

Huebner, A.J., Walker. A. J. and Mc Farland. M (2003). Staff development for the youth development professionalm: A critical Framework for understanding the work http:// www. Sage publications.com

Herman A. Kurt K. (2009). Benefit of Training and Development for Individual and Teams organisations and Society.

Margaret M. S. (2011). Border Security in Ghana: Challenges and Prospects

Muogbo U.S. (2013). The impact of employee motivation on organizational performance (A study of selected firms In Anambra state Nigeria).

Singh R.K. (2009). Welfare measures and it impact on manpower productivity. Assessed online on April 11, 2009.

Thisday paper, (2013). Nigeria porous borders and national insecurity. Better border management.

Wolff, S. (2008). Border management in the Mediterranean: internal and ethical challenges.

Walters, W. (2006). Border/control. European journal of social theory, 9(2), 187-203. 